\title{
Analysis of Recent Erosion Hazard Levels and Conservation Policy Recommendations for Lesti Subwatershed, Upper Brantas Watershed
}

\author{
Andi Setyo Pambudi ${ }^{1}$, Setyo Sarwanto Moersidik ${ }^{2}$, and Mahawan Karuniasa ${ }^{3}$
}

Corresponding author. Email: andi.pambudi@bappenas.go.id

Submitted: 202 1-02-19 | Accepted: 2021-04-26 | Published: 2021-04-30

\begin{abstract}
The reduced age function of Sengguruh Dam/Reservoir due to erosion in the upper of Brantas Watershed (Lesti Subwatershed area) interferes with its role in flood control, irrigation water supply, and the supply of most of the hydroelectricity in East Java Province, Indonesia. This study aims to estimate erosion, analyze the interrelationship of the causative factors, and provides environmental conservation direction. The research uses mixed methods. The quantitative method of erosion rates is done by calculating the Modify Universal Soil Loss Equation which is supported by GIS tools. The qualitative method is carried out with questionnaires and interviews in the Lesti Subwatershed area. The results showed that the current erosion rate in each ha of land (average) in the Lesti Subwatershed was 153,868 tons /ha/year (exceeding the tolerable erosion rate of 30 tons/ha/year). The rate of erosion in the Lesti Subwatershed has always increased in the last 14 years. Of the 12 Subdistricts in the Lesti watershed, as many as 6 Subdistricts are identified as having high levels of Erosion Hazards so that they were a priority to be handled, namely in the Wajak, Dampit, Tirtoyudo, Gedangan, Sumbermanjing Wetan, and Bantur Subdistricts. Dampit Subdistrict, Turen Subdistrict, and Gondanglegi Subdistrict also face behavioral problems and high population pressure compared to other Subdistricts. Research also shows that there is a relationship between erosion and knowledge, attitudes, and behavior of the community in the form of population pressure and land use patterns. It is recommended that environmental conservation directives focus on these 6 Sub-districts through the application of soil and water conservation. The results of spatial analysis at priority locations suggest conservation measures in the form of law enforcement or counseling, and community empowerment to increase the ability and independence of the community through providing access to resources, education, and training.
\end{abstract}

Keywords: Conservation, Erosion, Population Pressure, Community Behavior, Watershed

\footnotetext{
${ }^{1}$ Directorate of Monitoring, Evaluation and Control of Regional Development, Ministry of National Development Planning / Bappenas

${ }^{2}$ Faculty of Engineering, University of Indonesia, Depok Campus, West Java, Indonesia

${ }^{3}$ Postgraduate School of Environmental Sciences, University of Indonesia, Salemba Campus, Jakarta, Indonesia
} 


\title{
Analysis of Recent Erosion Hazard Levels and Conservation Policy Recommendations for Lesti Subwatershed, Upper Brantas Watershed
}

\author{
Andi Setyo Pambudi, Setyo Sarwanto Moersidik, and Mahawan Karuniasa
}

\section{Introduction}

Erosion and sedimentation have been recognized as important issues that reduce reservoir capacity and destroy many public facilities (Setyawan \& Lee, 2017). Analyzing erosion and sedimentation cannot be released from the hydrological boundary of the Watershed (Anache et al., 2018; Bisri et al., 2017; Asdak, 2010). Dwelling or hydrological containers of economic activity based on the environment are described as watersheds (Common \& Stagl 2005; Miller \& Spoolman 2015; Reddy et al., 2017). Watershed areas are often used as socioeconomic, biophysical or political units for the management and planning of natural resources (Pambudi, 2019; Heathcote, 1998). Global climate change, increasing population and the intensity of economic activity are accelerating changes in watershed conditions which affect erosion where destroy is often caused by mismanagement in the upstream, such as the addition of cultivated and also residential land areas (Bellfield et al., 2015; Kindu et al. ., 2017; Euler et al., 2018).

The government has responded to the importance of restoring watershed conditions through the National Mid-Term Development Plan (RPJMN) 2015-2019 and 2020-2024 (GoI, 2014a). In this document, 15 priority watersheds are determined to be restored, one of them is the Brantas watershed (Bappenas, 2015). One of the upstream of the Brantas watersheds is the Lesti Subwatershed. Previous studies of erosion in this area show a significant increase in erosion rates. Yupi (2006) has calculated the erosion rate, especially the average of each hectare of land about 30.57 tons/ha/ year. The results of Setyono and Prasetyo (2012) showed an erosion rate of 105,763 tons/ha/year. Meanwhile, the study of Ma'wa et al. (2015) got 131,098 tons/ha/year. The erosion rate needs to be lowered and controlled in following the provisions that require further study.

Wischmeier and Smith (1978) in Arsyad (2006) state that the value of erosion rate or tolerable soil erosion $(\mathrm{T})$ in each hectare of land that can be tolerated for land in America is 4.48-11.21 tons/ha/year. The maximum rate of soil erosion in each hectare of land tolerated by many researchers for Indonesia is based on research of Hardjowigeno (1995), which is 30 tons / ha / year.

Ideally, erosion data in the watershed should be updated regularly so that the handling policy can be under the existing factual conditions (Pambudi \& Moersidik, 2019). The average erosion rate in the Lesti Subwatershed that can be tolerated is 30 tons/ha/year. When the erosion rate in the Lesti Subwatershed exceeds the tolerance limit, conservation is needed to control erosion rate so that sedimentation downstream can be reduced (Pambudi et al., 2020; Jeloudar et al., 2018; Nabi et al, 2017). Conservation efforts that are not proportional to the erosion rate have an impact on the magnitude of sedimentation in the Sengguruh Reservoir making the reservoir function is not optimal (Firdaus et al., 2015; Djajasinga et al., 2012). Conservation considerations require erosion rate data as well as soil solum which will 
spatially describe the Erosion Hazard Level (EHL) values in the Lesti Subwatershed (Pambudi et al., 2020). This study is expected to provide recommendations for conservation actions that are in line with current EHL in the Lesti Subwatershed, including considering social aspects and population pressure.

This study aims to: 1) Analyze the influence of population pressure, community behavior, and land use on erosion in the Lesti Subwatershed; 2) Estimate the latest erosion in the Lesti Subwatershed and; 3) Provide conservation direction in the Lesti Subwatershed based on erosion estimation, population pressure and community behavior as part of efforts to restore the health of the Brantas watershed. The research uses a watershed ecological and conservation approach framework that covers economic, social, and environmental aspects. The results of the study are expected to be considered by policy makers or the public regarding the selection of appropriate conservation sites and conservation efforts that must be based on scientific analysis of hydrological and ecological sciences.

\section{Material And Methods}

This paper utilized literature study through referencing relevant theories and informationbased policies of forestry and social forestry. The utilized secondary data were obtained or collected from various existing sources as books, documents, and applicable laws and regulations related to social forestry, both in the context of Indonesia and that of the world. Analysis of the gap or suitability between targets and realization was used as a basis for providing research recommendations in addition to the problems or obstacles encountered in social forestry policy in Indonesia.

\subsection{Time and Location}

The time for completing research was carried out from February 2019 to January 2020 (for 12 months). The research location is limited to the Lesti Subwatershed as one of the upstream of Brantas watersheds. Administratively, the Lesti Subwatershed is located in Malang District (Kabupaten Malang) with the total area of the Subwatershed is 64,740.84 ha. The research sites cover 12 Subdistricts in Malang District. The limitation of the study area starts from the headwaters of the Lesti River in Poncokusumo Subdistrict to the Sengguruh Dam (outlet).

\subsection{Materials and Tools}

In conducting research, secondary data from relevant agencies in the Brantas Watershed area are used, such as: 1) Rain data for the last 10 years from The Public Works and Water Resources Department of East Java Province; 2) Topographic Map, Soil Solum, Soil Type, Soil Texture and the latest 2018 Land Use Map from the Ministry of Environment and Forestry, specifically Brantas Watershed and Protected Forest Management Center (BPDAS-HL); 3) Data related to land tables from experts which have been agreed by many researchers in advance; 4) Contour and River maps of 1: 25,000 scale covering the Lesti Subwatershed area of the Geospatial Information Agency (GIA). This map consists of 7 sheet maps with indices 1607-414 Manjing Wetan Resources, 1607-423 Gamping, 1607-432 Turen, and 1607-441 Tlogosari, 1607-434 Bululawang, 1607-443 Tumpang, 1607-444 Ranupane; 5) Monograph data from BPS and; 6) Questionnaire Data (Primary Data). 
The research design was carried out by giving 3 questionnaires namely a knowledge questionnaire sheet, an attitude questionnaire sheet, and a behavioral questionnaire sheet for the selection of environmental-related activities in the Lesti Subwatershed. The completion of the questionnaire was carried out through direct visits on 17 to 30 July 2019 or online via the bit.ly/SubDASLesti link with a total of 358 respondents in 12 Subdistricts in the Lesti Subwatershed. The analytical tool used is by using the help of Arc GIS 10.3 Software, SPSS Version 22 and Microsoft Excel 2019.

\subsection{Research Methods}

The method used is a mixed method with community behavior analysis using cross tabulation statistical analysis methods. Behavior analysis design starts from the results of a questionnaire-based survey in order to determine the relationship between attitudes, knowledge and behavior of the community with a sample analysis scale of 358 respondents in Malang District (12 Subdistricts) who are in the scope of the Lesti Subwatershed. The research ethics used was informed consent and confidentiality. The results of this survey form the basis for calculating Pearson's bivariate correlation in statistical science. Delegation of the Lesti Subwatershed is carried out by generating Digital Elevation Model (DEM) data from the Earth Map, in particular the 1: 25,000 scale Contour and River Maps covering the Lesti Subwatershed area from the Geospatial Information Agency (GIA). Rain data consistency test uses the double mass curve approach (Soemarto, 1987) and the calculation of regional maximum rainfall uses Polygon Thiessen. Analysis of rainfall design using the Pearson Log Type III distribution and 1.01 return time. To calculate surface runoff discharge, a modified rational formula is used. The calculation in this study such as: 1) Determine the Flow Coefficient (C); 2) Calculate the Concentration Time (Tc), Reservoir Coefficient (Cs) and Rain Intensity (I) and; 3) Running formula of runoff discharge and describe it in the form of Surface Runoff Discharge Distribution Map in various times with Arc GIS Software 10.3. Analysis related to population pressure using the Soemarwoto Formula (1985) and behavior analysis using the Pearson bivariate statistical method. The erosion rate was calculated by the MUSLE method with a database of surface runoff erosivity index, erodibility, length and slope as well as crop management factors and conservation measures $(\mathrm{CP})$. The component of obtaining $\mathrm{CP}$ value is also related to community behavior and population pressure on land. Meanwhile, to get the level of erosion hazard an overlay is done between the erosion rate map and the soil solum map with the help of Geographic Information System tools. Conservation action recommendations use overlay techniques from attributes entered under Law 37 of 2014 on Soil and Water Conservation (GoI, 2014b).

\section{Results And Discussion}

\subsection{Behavior Analysis}

Analysis of Knowledge, Attitudes and Behavior in Lesti Subwatershed using pearson bivariate correlation analysis. This analysis was conducted to determine the closeness of the relationship between variables expressed by the correlation coefficient. This study uses SPSS software that is used to simplify the process of correlation analysis. There are three ways that can be used as a guide / basis for decision making in Pearson's bivariate correlation 
analysis, which is based on the significance value of sig. (2-tailed), based on $r$ count values (Pearson correlations) and based on asterisks (*) in SPSS software.

The results of the SPSS software analysis to look for correlations of community knowledge, attitudes and behavior in the Lesti Subwatershed are shown in Table 1.

Table 1. Behavior Variable Correlation with the Knowledge Variable and Attitude Variable

\begin{tabular}{llr|r}
\hline & & Knowledge & \multicolumn{1}{c|}{ Attitude } \\
\hline Behavior & Correlation of Pearson & $.629^{* *}$ & $.188^{* *}$ \\
\cline { 2 - 4 } & Sig. (2-tailed) & .000 & .000 \\
\cline { 2 - 4 } & $\mathrm{N}$ & 358 & 358 \\
\hline
\end{tabular}

**. Correlation is significant at the 0.01 level (2-tailed).

Source: Analysis Result, 2019

From this table it can be concluded that there is a relationship or there is a correlation between the behavior variable with the knowledge variable and attitude variable. Knowledge is in harmony with attitudes and behavior. In spatial analysis, behavioral variables are used because statistically they already represent the knowledge and attitudes of the people in the Lesti sub watershed. Questionnaires that have been filled out by respondents are then assessed or scored. If the respondent's value is above the median value then the value is classified as positive, conversely if the respondent's value is below the median value then it is classified as negative. The median value of each variable can be seen in Table 2 .

Table 2. Median Values of Knowledge, Attitudes, and Behavior Variables

\begin{tabular}{lccc}
\hline \multirow{2}{*}{ median } & Knowledge & Attitude & Behavior \\
\cline { 2 - 4 } & 50 & 60 & 80 \\
\hline
\end{tabular}

Source: Analysis Result, 2019

The value of each respondent is then summarized in a cross tabulation per each Subdistrict.

Table 3. Percentage of Acquisition Values in Each Subdistrict

\begin{tabular}{|c|c|c|c|c|c|c|c|}
\hline \multirow{2}{*}{ Subdistrict } & \multicolumn{2}{|c|}{ Knowledge } & \multicolumn{2}{|c|}{ Attitude } & \multicolumn{2}{|c|}{ Behavior } & \multirow{2}{*}{$\begin{array}{c}\text { Total } \\
\text { Responden } \\
\text { t per } \\
\text { Subdistrict }\end{array}$} \\
\hline & negative & positive & negative & positive & negative & positive & \\
\hline Ampelgading & $1(3 \%)$ & $31(97 \%)$ & $1(3 \%)$ & $31(97 \%)$ & $2(6 \%)$ & $30(94 \%)$ & 32 \\
\hline Bantur & $25(81 \%)$ & $6(19 \%)$ & $12(39 \%)$ & $19(61 \%)$ & $17(55 \%)$ & $14(45 \%)$ & 31 \\
\hline Bululawang & $\mathrm{O}(0 \%)$ & $\begin{array}{c}30 \\
(100 \%)\end{array}$ & $1(3 \%)$ & $29(97 \%)$ & $1(3 \%)$ & $29(97 \%)$ & 30 \\
\hline Dampit & $29(94 \%)$ & $2(6 \%)$ & $\begin{array}{c}31 \\
(100 \%)\end{array}$ & $0(0 \%)$ & $28(90 \%)$ & $3(10 \%)$ & 31 \\
\hline Gedangan & $22(71 \%)$ & $9(29 \%)$ & $18(58 \%)$ & $13(42 \%)$ & $18(58 \%)$ & $13(42 \%)$ & 31 \\
\hline Gondanglegi & $14(47 \%)$ & $16(53 \%)$ & $10(33 \%)$ & $20(67 \%)$ & $20(67 \%)$ & $10(33 \%)$ & 30 \\
\hline Pagak & $10(40 \%)$ & $15(60 \%)$ & $7(28 \%)$ & $18(72 \%)$ & $7(28 \%)$ & $18(72 \%)$ & 25 \\
\hline Poncokusumo & $4(15 \%)$ & $22(85 \%)$ & $\mathrm{O}(0 \%)$ & $\begin{array}{c}26 \\
(100 \%)\end{array}$ & $2(8 \%)$ & $24(92 \%)$ & 26 \\
\hline
\end{tabular}




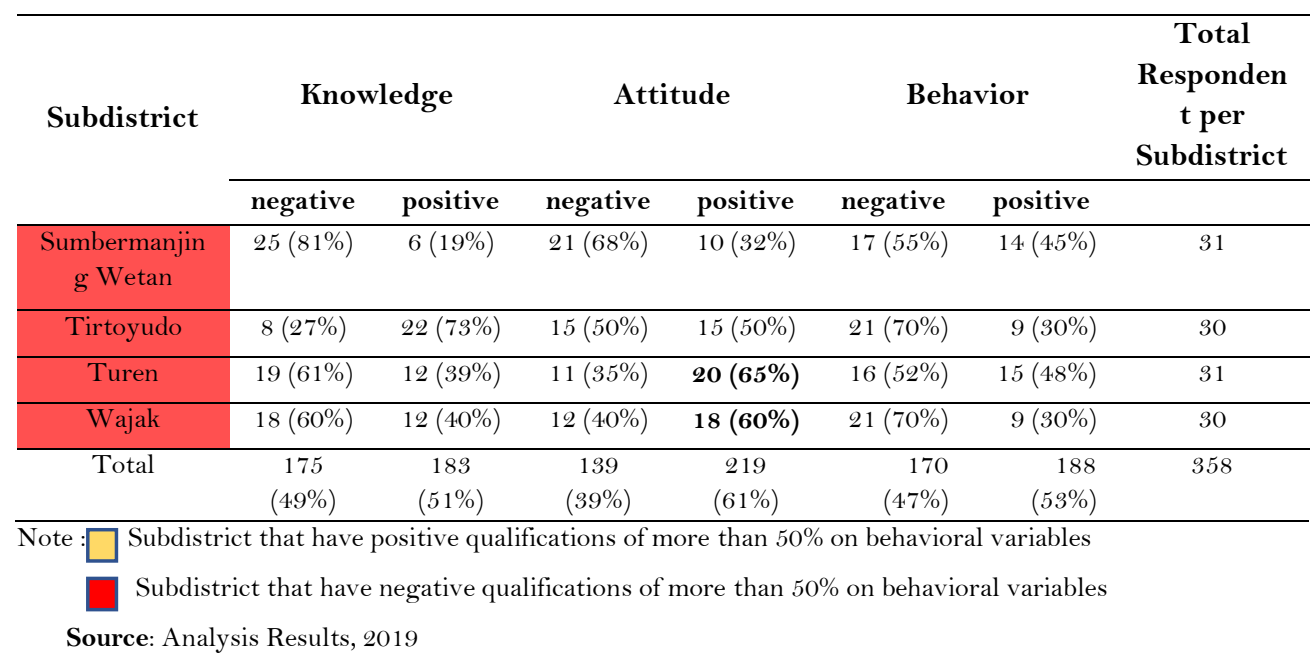

Based on the cross tabulation, Subdistricts that have a positive value of more than $70 \%$ or can be said to be good Subdistricts in the management behavior of Lesti Subwatershed are Ampelgading, Bululawang, Pagak, and Poncokusumo Subdistricts. Not only do these four Subdistricts have good grades on behavioral variables, but they are also good at attitudes and knowledge related to watershed management. In the analysis also found Subdistricts that have less value on the behavior variable (classified as negative more than $50 \%$ ), namely the Subdistricts of Dampit, Gedangan, and Sumbermanjing Wetan, Bantur, Gondanglegi, Tirtoyudo, Turen and Wajak. Subdistricts that are less good in behavior also tend to lack in attitudes and behavior.

The results of the statistical and spatial analysis show that in the Lesti Subwatershed there is a link or correlation between the people's behavior and the existing land use. Overlay of spatial maps of behavior with the latest land use states that in Subdistricts that are dominated by negative values tend to have land use that is potentially prone to erosion, namely open or semi-open land such as settlements, dry land agriculture, mixed dryland agriculture, paddy fields, and open land.

\subsection{Population Pressure Analysis}

Ariani et al., 2012, said that the TP value $<1$ means that there was no population pressure. It's showed the area was still able to support the population's living needs. Value of TP $=1$ means that the area is still able to support the living needs of its inhabitants appropriately. Value of TP $>1$ means that there has been a population pressure on the land in an area so that it has been unable to support the needs of life of its residents properly (Sapci \& Considine, 2014; Rusli et al., 2009). Population pressure on land is calculated by the formula Otto Soemarwoto (1985) as follows: 


$$
\mathrm{TP}=\mathrm{Z} \times \frac{\mathrm{f} P \mathbf{0}(1+r)^{t}}{\mathrm{~L}}
$$

There is an explanation of the formula. The TP means population pressure and $\mathrm{Z}$ related to minimum land area per farmer to be able to live properly. Furthermore,

$\mathrm{t} \quad=$ Time span in years

$\mathrm{L} \quad=$ Total area of agricultural land

$\mathrm{r} \quad=$ The average population growth rate per year

Po $\quad=$ Total population of the initial year

$\mathrm{f} \quad=$ Proportion of farmers in population $(\%)$

Each farmer minimum land to be able to live properly ( $\mathrm{Z}$ value) is formulated as follows:

$$
Z=\frac{\left(0.25 L S I_{2}\right)+\left(0.5 L S I_{1}\right)+(0.5 L S T)+(0.76 L L K)}{\left(L S I_{2}+L S I_{1}+L S T+L L K\right)}
$$

(Formula 2)

There is an explanation of the formula.

$\mathrm{LSI}_{1}=$ Irrigated rice field area 1 harvest a year (ha)

$\mathrm{LSI}_{2}=$ Irrigated rice field area from 2 times a year harvest (ha)

LST = Rainfed lowland area (ha)

LLK = Dry land area $($ ha $)$

The proportion value of farmers in the population ( $\mathrm{f}$ ) is obtained from the formula submitted by Soemarwoto (1985), namely:

$\mathrm{f}=$ (Total farmers / Total people population) $\mathrm{x} \mathrm{100 \%}$

(Formula 3)

The population growth rate is using the geometry formula as follows:

$\mathrm{Pt}=\mathrm{Po}(1+\mathrm{r})^{\mathrm{t}}$

(Formula 4)

Where:

$\mathrm{Pt}=$ Total population in the year $\mathrm{t}$

Po $=$ Total population of the initial year

$\mathrm{r} \quad=$ Population growth rate

$\mathrm{t} \quad=$ The time period, which is stated in years. 
Table 4. Population Pressure Level on Land

\begin{tabular}{|c|c|c|c|c|c|c|c|c|}
\hline $\begin{array}{l}\text { Subdistrict in } \\
\text { Lesti } \\
\text { Subwatershed }\end{array}$ & $\begin{array}{c}\text { Tot } \\
\text { al } \\
\text { Pop } \\
\text { ulati } \\
\text { on }\end{array}$ & $\begin{array}{l}\text { Total } \\
\text { Farm } \\
\text { er }\end{array}$ & $\begin{array}{l}\text { Proporti } \\
\text { on of } \\
\text { Farmer }\end{array}$ & $\begin{array}{l}\text { Populatio } \\
\text { n Growth } \\
\text { Rate }\end{array}$ & $\begin{array}{l}\text { Minimum } \\
\text { Area Worth } \\
\text { Living }\end{array}$ & $\begin{array}{l}\text { Land Area } \\
\text { for } \\
\text { Agriculture } \\
\text { (Ha) }\end{array}$ & $\begin{array}{l}\text { Populati } \\
\text { on } \\
\text { Pressure }\end{array}$ & $\begin{array}{c}\text { Cri } \\
\text { ter } \\
\text { ia }\end{array}$ \\
\hline Poncokusumo & $\begin{array}{r}26.2 \\
21 \\
\end{array}$ & $\begin{array}{r}24.46 \\
0 \\
\end{array}$ & 0,93 & 1,53 & 0,17 & $4.226,381$ & 0,97542 & $\begin{array}{l}< \\
1 \\
\end{array}$ \\
\hline Wajak & $\begin{array}{r}74.1 \\
21 \\
\end{array}$ & $\begin{array}{r}66.29 \\
2 \\
\end{array}$ & 0,89 & 1,20 & 0,19 & $4.621,481$ & 0,87528 & $\begin{array}{l}< \\
1 \\
\end{array}$ \\
\hline Dampit & $\begin{array}{r}108 . \\
914 \\
\end{array}$ & $\begin{array}{r}89.08 \\
7 \\
\end{array}$ & 0,82 & 1,50 & 0,19 & $8.361,963$ & 3,61627 & $\begin{array}{l}> \\
1\end{array}$ \\
\hline Tirtoyudo & $\begin{array}{r}44.1 \\
21 \\
\end{array}$ & $\begin{array}{r}28.99 \\
1 \\
\end{array}$ & 0,66 & 1,44 & 0,17 & $3.029,741$ & 0,86021 & $\begin{array}{l}< \\
1 \\
\end{array}$ \\
\hline $\begin{array}{l}\text { Sumbermanjin } \\
\text { g Wetan }\end{array}$ & $\begin{array}{r}24.7 \\
39 \\
\end{array}$ & $\begin{array}{r}15.09 \\
9 \\
\end{array}$ & 0,61 & 1,47 & 0,19 & $1.548,180$ & 0,55234 & $\begin{array}{l}< \\
1 \\
\end{array}$ \\
\hline Turen & $\begin{array}{r}107 . \\
607 \\
\end{array}$ & $\begin{array}{r}61.44 \\
5 \\
\end{array}$ & 0,57 & 1,68 & 0,16 & $3.713,927$ & 3,68583 & $\begin{array}{l}> \\
1\end{array}$ \\
\hline Bululawang & $\begin{array}{r}12.2 \\
82 \\
\end{array}$ & 4.927 & 0,40 & 0,72 & 0,16 & 209,196 & 0,00427 & $\begin{array}{l}< \\
1 \\
\end{array}$ \\
\hline Gondanglegi & $\begin{array}{r}82.0 \\
52 \\
\end{array}$ & $\begin{array}{r}57.98 \\
4 \\
\end{array}$ & 0,70 & 1,50 & 0,16 & $5.444,617$ & 1,95847 & $\begin{array}{l}> \\
1\end{array}$ \\
\hline Ampelgading & $\begin{array}{r}14.8 \\
23 \\
\end{array}$ & 9.084 & 0,69 & 1,24 & 0,16 & 307,824 & 0,13464 & $\begin{array}{l}< \\
1\end{array}$ \\
\hline Gedangan & $\begin{array}{r}12.0 \\
32 \\
\end{array}$ & 5.043 & 0,42 & 0,19 & 0,26 & $1.329,656$ & 0,00001 & $\begin{array}{l}< \\
1 \\
\end{array}$ \\
\hline Bantur & $\begin{array}{r}20.3 \\
84 \\
\end{array}$ & $\begin{array}{r}13.05 \\
1 \\
\end{array}$ & 0,64 & 0,66 & 0,26 & $1.757,160$ & 0,01192 & $\begin{array}{l}< \\
1 \\
\end{array}$ \\
\hline Pagak & $\begin{array}{r}7.68 \\
3 \\
\end{array}$ & 7.123 & 0,93 & 1,49 & 0,26 & $1.082,391$ & 0,38289 & $\begin{array}{l}< \\
1 \\
\end{array}$ \\
\hline
\end{tabular}

Source: Analysis Results, 2019

\subsection{Erosion Analysis}

Meanwhile, related to hydrological analysis as data to support erosion calculations, watershed delineation is needed. The delineation process is carried out with the help of Geographic Information System (GIS) tools, specifically the ArcGIS software. 


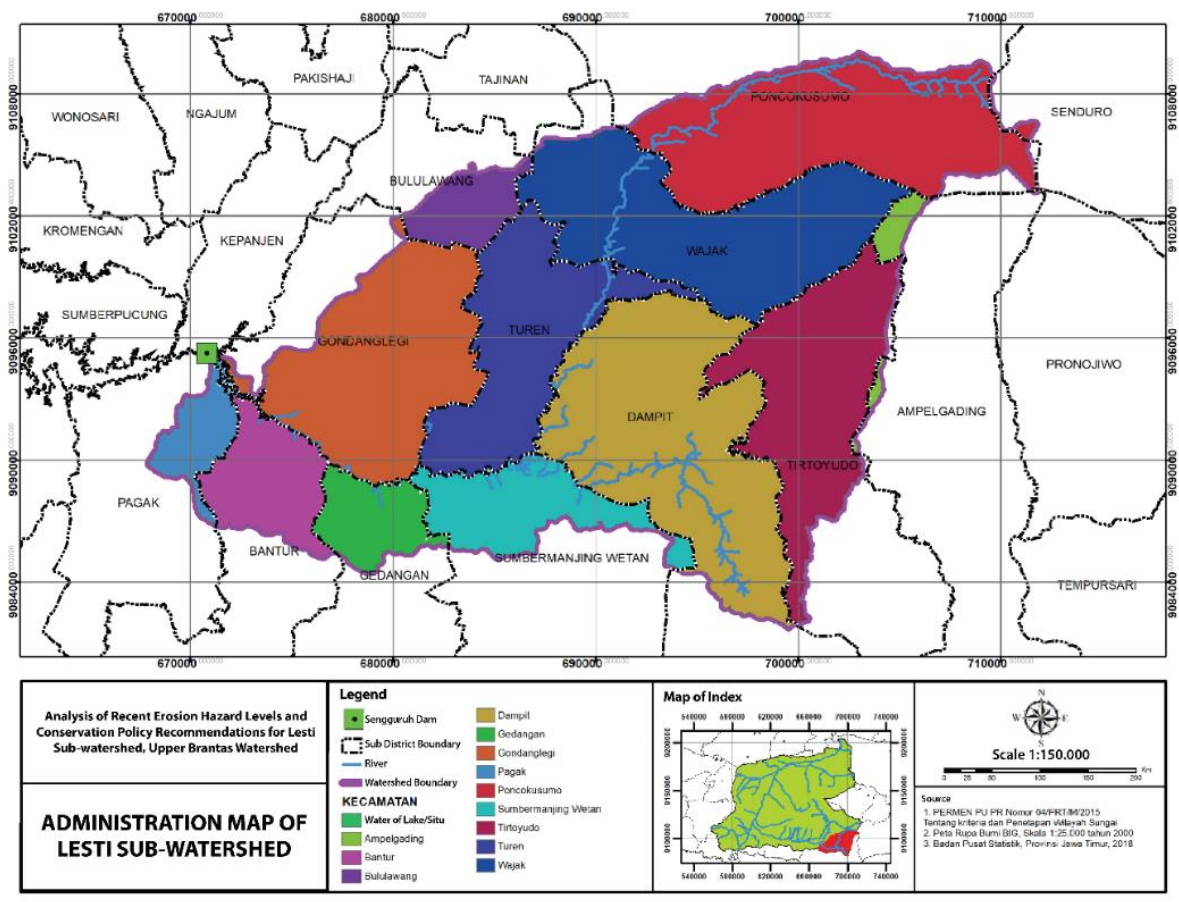

Figure 1. Results of Overlay Delineation of Watershed Boundaries and Sub District Boundaries of Lesti Subwatershed

Source: Analysis Results, 2021

Delineation begins by changing the contour map to DEM, then determining the direction of flow direction, flow accumulation, defining the river network synthetically, determining the outlet then finally defining the watershed and calculating watershed parameters. The shape and area of a watershed are influenced by the position of the outlet of a watershed. Lesti Subwatershed is located in Malang District with the total area of the Subwatershed is 64,740.84 ha. The research sites cover 12 Subdistrict. Study location starts from the headwaters of the Lesti River in Poncokusumo Subdistrict to the Sengguruh Reservoir outlet.

Rainfall data consistency test with the double mass curve method shows that the available rain data can be used for further analysis. In determining the regional average rainfall, this study method uses the Thiessen Polygon. This polygon is depicted by entering the coordinates of 4 rain stations with the help of ArcGIS 10.3 software to get the rain station distribution map in the Lesti Subwatershed Map. The next process is to create a Thiessen Polygon through assign proximity with a map of the Lesti watershed as a boundary of the area of influence.

From the result analysis, the Turen Rain Station has the largest area of influence that is $26,496,837 \mathrm{Ha}(40,928 \%$ or thiessen coefficient 0,409), after that the Dampit Station is $23,731,127 \mathrm{Ha}(36,665 \%$ or thiessen coefficient 0,367), Poncokusumo Station 13,257,853 Ha (afterwards 20,478\% or thiessen coefficient 0,205) and the last is T Crafts Station 1,255,021 Ha $(1,938 \%$ or thiessen coefficient 0,019$)$. 
Table 5. Regional Average Daily Maximum Rainfall (2009-2018)

\begin{tabular}{|c|c|c|c|c|c|c|}
\hline \multirow{3}{*}{$\begin{array}{c}\text { Numbe } \\
\text { r. }\end{array}$} & \multirow{3}{*}{$\begin{array}{c}\text { Yea } \\
\mathrm{r}\end{array}$} & \multicolumn{4}{|c|}{ Koefisien Thiessen } & \multirow{3}{*}{$\begin{array}{c}\text { Maximum Rainfall Average Daily } \\
\text { Area }\end{array}$} \\
\hline & & $\begin{array}{c}\text { Stat. } \\
\text { Poncokusumo }\end{array}$ & $\begin{array}{c}\text { Stat. } \\
\text { Damp } \\
\text { it }\end{array}$ & $\begin{array}{c}\text { Stat } \\
\text { Tajinan }\end{array}$ & $\begin{array}{l}\text { Stat. } \\
\text { Turen }\end{array}$ & \\
\hline & & 0,205 & 0,367 & 0,019 & 0,409 & \\
\hline \multirow{2}{*}{1} & 200 & & & & & \\
\hline & 9 & 150 & 117 & 71 & 127 & 126,959 \\
\hline \multirow{2}{*}{2} & 201 & & & & & \\
\hline & 0 & 85 & 106 & 79 & 68 & 85,624 \\
\hline \multirow[b]{2}{*}{3} & 201 & & & & & \\
\hline & 1 & 94 & 108 & 79 & 100 & 101,297 \\
\hline \multirow{2}{*}{4} & 201 & & & & & \\
\hline & 2 & 79 & 89 & 60 & 69 & 78,204 \\
\hline \multirow[b]{2}{*}{5} & 201 & & & & & \\
\hline & 3 & 110 & 109 & 69 & 115 & 110,885 \\
\hline \multirow{2}{*}{6} & 201 & & & & & \\
\hline & 4 & 115 & 75 & 76 & 102 & 94,261 \\
\hline \multirow{2}{*}{7} & 201 & & & & & \\
\hline & 5 & 95 & 74 & 71 & 63 & 73,740 \\
\hline \multirow{2}{*}{8} & 201 & & & & & \\
\hline & 6 & 75 & 89 & 64 & 83 & 83,193 \\
\hline \multirow{2}{*}{9} & 201 & & & & & \\
\hline & 7 & 115 & 147 & 114 & 88 & 115,660 \\
\hline \multirow{2}{*}{10} & 201 & & & & & \\
\hline & 8 & 85 & 103 & 73 & 74 & 86,863 \\
\hline
\end{tabular}

Source: Analysis Results, 2019

In hydrological analysis, the next process in order to predict erosion in the Lesti sub watershed is to calculate the design rainfall. The definition of design rainfall can be interpreted as the greatest rainfall that is likely to occur in an area with certain opportunities. In this study, the method for analyzing design rain is the Log Pearson Type III method.

Table 6. Calculation of the Pearson Type III Log Distribution (2009-2018)

\begin{tabular}{ccccccc}
\hline Number. & Year & Xi $(\mathrm{mm})$ & $\mathrm{P}(\%)$ & $\log$ Xi & $\log$ Xi-Log X & $(\log \text { Xi-Log X })^{3}$ \\
\hline 1 & 2015 & 73,74 & 9,09 & 1,87 & $-0,11$ & $-0,001215$ \\
\hline 2 & 2012 & 78,20 & 18,18 & 1,89 & $-0,08$ & $-0,000535$ \\
\hline 4 & 2016 & 83,19 & 27,27 & 1,92 & $-0,05$ & $-0,000160$ \\
\hline 5 & 2010 & 85,62 & 36,36 & 1,93 & $-0,04$ & $-0,000073$ \\
\hline 6 & 2018 & 86,86 & 45,45 & 1,94 & $-0,04$ & $-0,000045$ \\
\hline 7 & 2014 & 94,26 & 54,55 & 1,97 & 0,00 & 0,000000 \\
\hline 8 & 2011 & 101,30 & 63,64 & 2,01 & 0,03 & 0,000030 \\
\hline 9 & 2017 & 115,88 & 72,73 & 2,04 & 0,07 & 0,000350 \\
\hline 10 & 2009 & 126,96 & 81,82 & 2,06 & 0,09 & 0,000700 \\
\hline Total & 956,69 & 2,10 & 0,13 & 0,002159 \\
\hline Average & 95,67 & 19,74 & 0,001211 \\
\hline Stand. Dev & & 17,52 & 1,97 & \\
\hline \multicolumn{7}{c}{ Skewness (Cs) } \\
\hline
\end{tabular}

Source: Analysis Results, 2019

$\mathrm{Xi}=$ Regional Average Rainfall (after being sorted from small to large). 
The return period ( $\mathrm{Tr}$ ) is calculated by taking the various opportunities/possibilities desired. The reset time is determined by the formula $\operatorname{Tr}=(1 /$ chance $) \times 100 \%$. The calculation in this analysis will use a return with the greatest chance of $99 \%$ (assuming there is no $100 \%$ certain chance) so that the return period with this opportunity is 1.01 years. Calculations of the design rainfall values with a variety of complete returns are presented in Table 7.

Table 7. Calculation of Design Rain with Various Returns

\begin{tabular}{ccccccccc}
\hline Number & $\begin{array}{c}\text { Tr } \\
(\text { year })\end{array}$ & $\begin{array}{c}\text { Average R } \\
(\mathrm{Log})\end{array}$ & $\begin{array}{c}\text { Std Dev. } \\
(\mathrm{Log})\end{array}$ & $\begin{array}{c}\text { Skewness } \\
(\mathrm{Cs})\end{array}$ & $\begin{array}{c}\text { Opprotunity } \\
(\%)\end{array}$ & K & \multicolumn{2}{c}{ Design Rainfall } \\
\hline$[1]$ & {$[2]$} & {$[3]$} & {$[4]$} & {$[5]$} & {$[6]$} & {$[7]$} & {$[8]$} & {$[9]$} \\
\hline 1 & 1,01 & 1,97 & 0,08 & 0,36 & 99 & $-2,061$ & 1,81 & 65,17 \\
\hline 2 & 2 & 1,97 & 0,08 & 0,36 & 50 & $-0,059$ & 1,97 & 93,28 \\
\hline 3 & 5 & 1,97 & 0,08 & 0,36 & 20 & 0,819 & 2,04 & 109,18 \\
\hline 4 & 10 & 1,97 & 0,08 & 0,36 & 10 & 1,314 & 2,08 & 119,29 \\
\hline 5 & 25 & 1,97 & 0,08 & 0,36 & 4 & 1,867 & 2,12 & 131,71 \\
\hline 6 & 50 & 1,97 & 0,08 & 0,36 & 2 & 2,240 & 2,15 & 140,81 \\
\hline 7 & 100 & 1,97 & 0,08 & 0,36 & 1 & 2,585 & 2,18 & 149,79 \\
\hline 8 & 1000 & 1,97 & 0,08 & 0,36 & 0,1 & 3,606 & 2,25 & 179,85 \\
\hline
\end{tabular}

Source: Analysis Results, 2019

Note:

$$
\begin{array}{ll}
{[1]=\text { Number }} & {[6]=(1 / \mathrm{Tr})^{*} 100} \\
{[2]=\text { Return Period }} & {[7]=\text { table of factors of log person distribution III }} \\
{[3]=(\text { SlogXi) } / \mathrm{n}} & \text { based on the value of Cs and opportunities or return } \\
{[4]=\left(\left(\sum(\operatorname{LogXi}-\log X)\right) /(\mathrm{n}-1)\right)^{0,5}} & {[8]=\log \mathrm{X}+\mathrm{K} \cdot \mathrm{Slog} \mathrm{X}} \\
{[5]=\left(\mathrm{n} \cdot \Sigma(\operatorname{LogXi}-\log \mathrm{X})^{3}\right) /((\mathrm{n}-1)(\mathrm{n}-} & {[9]=\text { antilog dari } \log \mathrm{X}} \\
\left.2)(\operatorname{SLogX})^{3}\right) &
\end{array}
$$

based on the value of $\mathrm{Cs}$ and opportunities or return period 


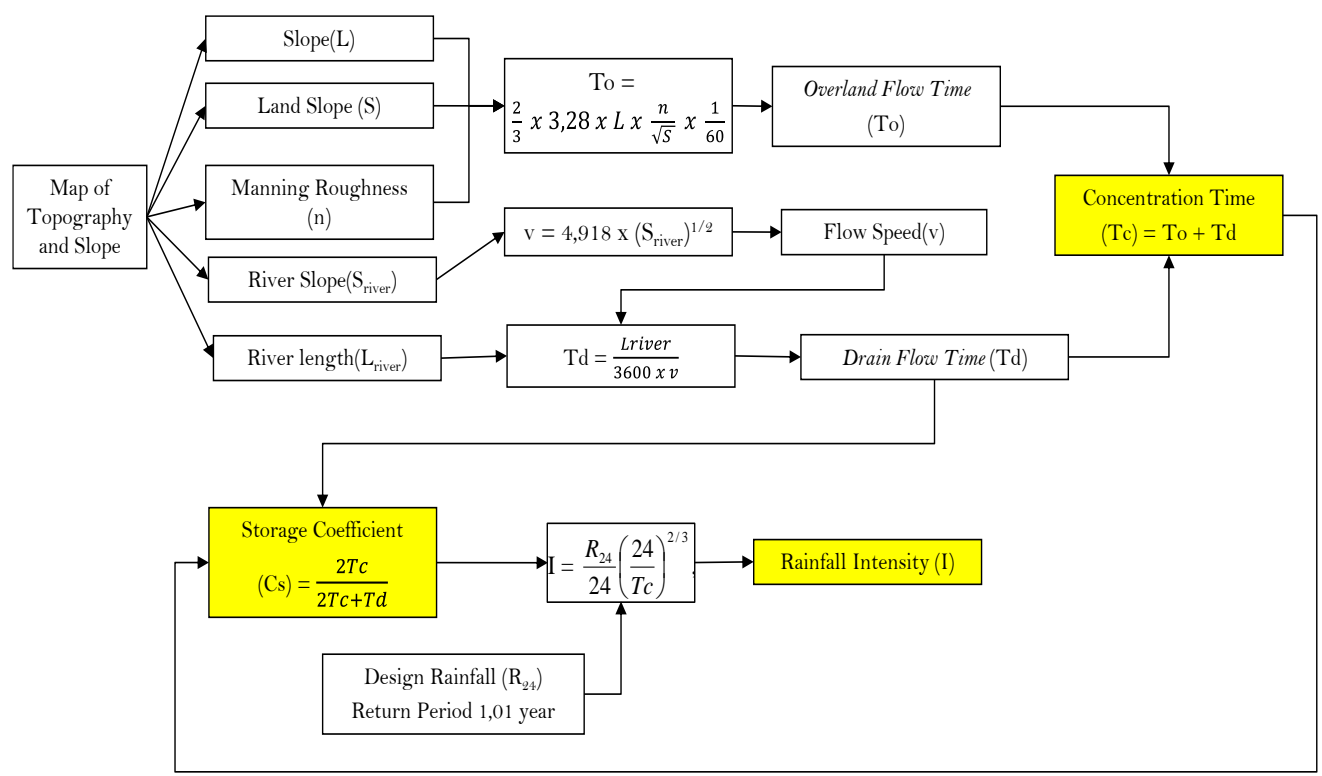

Figure 2. Flow Analysis of Concentration Time (Tc), Reservoir Coefficient (Cs) and Rain Intensity (I)

Source: Analysis Results, 2021

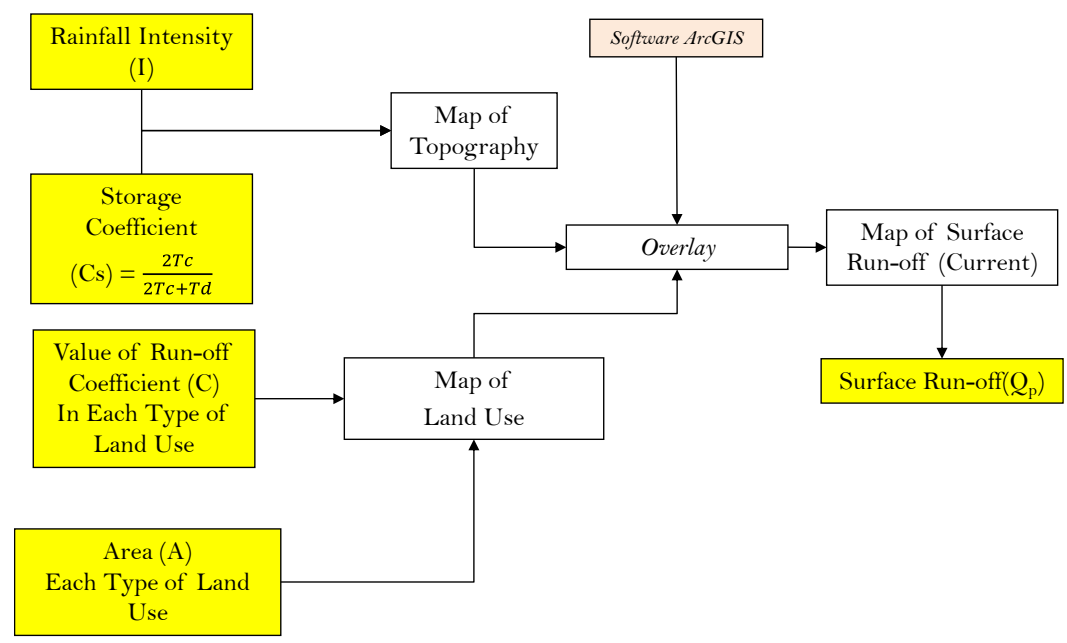

Figure 3. Flow Analysis of Surface Runoff Discharge Calculation in the Lesti

Subwatershed

Source: Analysis Results, 2021

The next step analysis is determine runoff discharge. This analysis is done through overlays using ArcGIS software. The data used are Coefficients Cs and I. Furtehermore, the data used 
are land use maps for Coefficient $\mathrm{C}$. The formula used is the modified rational runoff equation, namely:

$$
Q=0,00278 . \text { Cs. C. I. A }
$$

(Formula 5)

Table 8. Coefficient C (Runoff) of Lesti Subwatershed in 2018

\begin{tabular}{clrrrr}
\hline \multirow{2}{*}{ Number } & \multirow{2}{*}{ Land Use } & \multirow{2}{*}{ Coefficient C } & \multicolumn{1}{c}{ Area } & \multicolumn{1}{c}{ Area } & \multicolumn{2}{r}{ Percentage } \\
\cline { 3 - 6 } & & & \multicolumn{1}{c}{$\left(\mathrm{m}^{2}\right)$} & \multicolumn{1}{c}{$(\mathrm{Ha})$} & \multicolumn{1}{c}{$\%$} \\
\hline 1 & Water Body & 0,00 & 131396,37 & 13,14 & 0,02 \\
\hline 2 & Thicket & 0,15 & 4941972,16 & 494,20 & 0,76 \\
\hline 3 & Secondary Dry Land Forest & 0,08 & 67709252,20 & 6770,93 & 10,46 \\
\hline 4 & Plantation Forest & 0,06 & 27804756,09 & 2780,48 & 4,29 \\
\hline 5 & Plantation Graden & 0,20 & 9742083,24 & 974,21 & 1,50 \\
\hline 6 & Settlement & 0,25 & 140276061,24 & 14027,61 & 21,67 \\
\hline 7 & Dryland Farming & 0,25 & 39999030,37 & 3999,90 & 6,18 \\
\hline 8 & Mixed Dryland Farming & 0,25 & 125190399,28 & 12519,04 & 19,34 \\
\hline 9 & Rice Field & 0,05 & 231120165,15 & 23112,02 & 35,70 \\
\hline 10 & Open Land & 0,30 & 493283,91 & 49,33 & 0,08 \\
\hline & & Total & 647408400,00 & 64740,84 & 100,00 \\
\hline
\end{tabular}

Source: Analysis Results, 2019

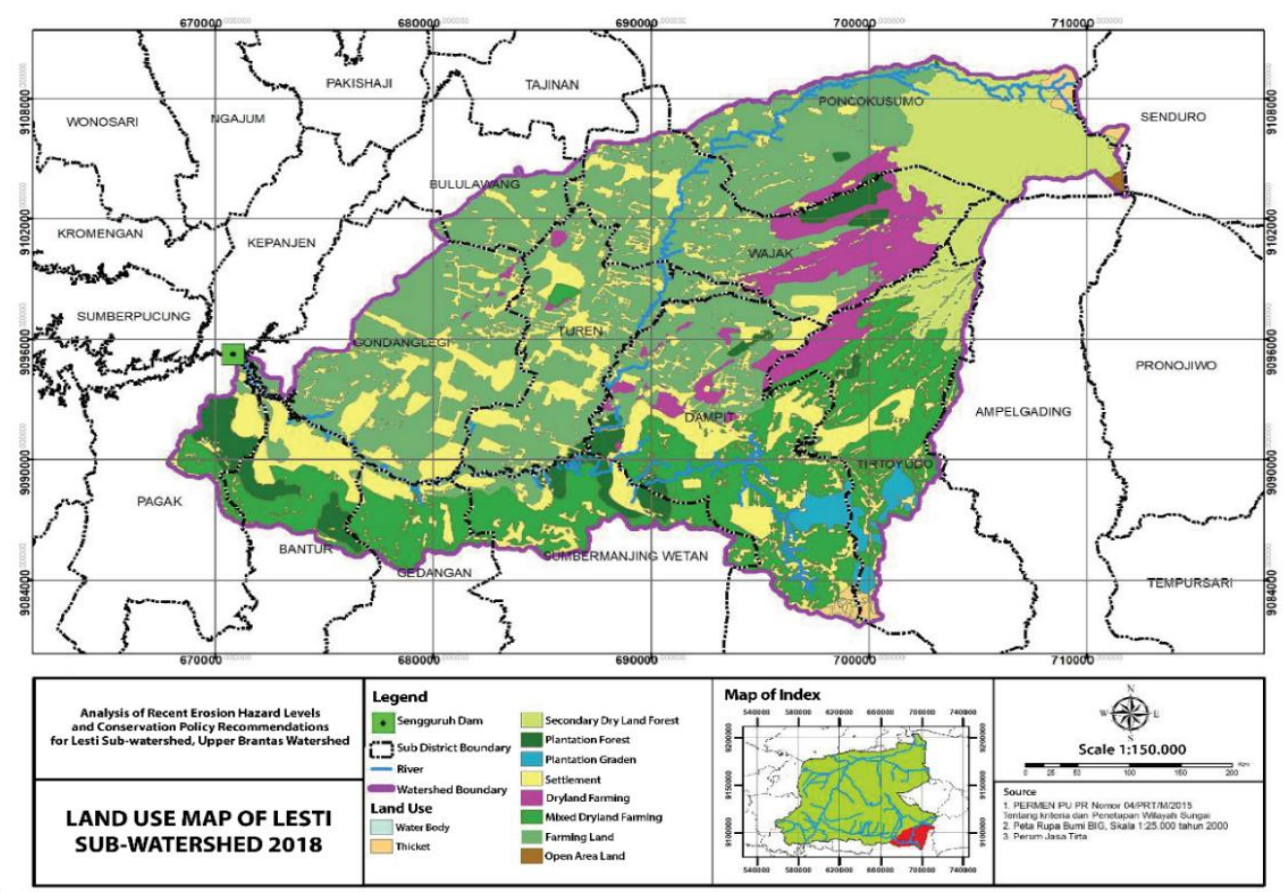

Figure 4. Land Use Map of Lesti Subwatershed 2018

Source: Analysis Results, 2021 
The value of surface runoff / runoff coefficient (C) which is large indicates that the amount of surface runoff that occurs in the land is large. This means that the condition of the water system and land use on the land have been damaged. The value of the surface runoff / small runoff coefficient shows that the amount of surface runoff that occurred on the land is small. This means that the amount of water that seeps into the ground and that contributes (recharge) groundwater is large. In this study, the magnitude of drainage coefficient values based on 2018 land use conditions in the Lesti Subwatershed can be seen in Table 9.

Table 9. Current Runoffs Discharge of Lesti Subwatershed

\begin{tabular}{|c|c|c|c|c|c|c|c|}
\hline \multirow{3}{*}{$\begin{array}{c}\text { Num } \\
\text { ber }\end{array}$} & \multirow{3}{*}{$\begin{array}{c}\text { Sub } \\
\text { Subwatershe } \\
\text { d }\end{array}$} & \multirow[t]{2}{*}{$\begin{array}{c}\text { Sub } \\
\text { Subwatershed } \\
\text { Area }\end{array}$} & \multirow{2}{*}{$\begin{array}{c}\text { Q } \\
\begin{array}{c}\text { Return } \\
\text { Period }\end{array} \\
1.01 \text { Year }\end{array}$} & \multirow{2}{*}{$\begin{array}{c}\text { Q } \\
\text { Return } \\
\text { Period }\end{array}$} & \multirow{2}{*}{$\begin{array}{c}\text { Q } \\
\text { Return } \\
\text { Period }\end{array}$} & \multirow{2}{*}{$\begin{array}{c}\text { Q } \\
\text { Return } \\
\text { Period }\end{array}$} & \multirow{2}{*}{$\begin{array}{c}\mathrm{Q} \\
\begin{array}{c}\text { Return } \\
\text { Period }\end{array} \\
25 \text { Years }\end{array}$} \\
\hline & & & & & & & \\
\hline & & (Ha) & $\left(\mathrm{m}^{3} / \mathrm{sec}\right)$ & $\left(\mathrm{m}^{3} / \mathrm{sec}\right)$ & $\left(\mathrm{m}^{3} / \mathrm{sec}\right)$ & $\left(\mathrm{m}^{3} / \mathrm{sec}\right)$ & $\left(\mathrm{m}^{3} / \mathrm{sec}\right)$ \\
\hline & & & & & 11,28896 & 12,33376 & 13,61843 \\
\hline 1 & 1 & 2244,76 & 6,738595 & 9,645109 & 5 & 4 & 3 \\
\hline 2 & 2 & 1272,64 & 3,804667 & 5,445708 & 6,373843 & 6,963745 & 7,689079 \\
\hline \multirow[t]{2}{*}{3} & 3 & 2585,00 & 4,276788 & 6,121467 & 7,164774 & 7,827877 & 8,643220 \\
\hline & & & & 14,19828 & 16,61815 & 18,15617 & 20,04730 \\
\hline 4 & 4 & 4662,40 & 9,919690 & 4 & 8 & 4 & 2 \\
\hline \multirow[t]{2}{*}{5} & 5 & 171,96 & 0,569628 & 0,815321 & 0,954280 & 1,042599 & 1,151195 \\
\hline & & & 10,38597 & 14,86568 & 17,39930 & 19,00961 & 20,98963 \\
\hline 6 & 6 & 3090,40 & O & 2 & 3 & 5 & 6 \\
\hline \multirow[t]{2}{*}{7} & 7 & 317,52 & 0,937318 & 1,341604 & 1,570259 & 1,715588 & 1,894281 \\
\hline & & & & 14,10490 & 16,50886 & 18,03676 & 19,91545 \\
\hline 8 & 8 & 2945,28 & 9,854448 & 4 & 1 & 4 & 3 \\
\hline 9 & 9 & 140,48 & 0,313284 & 0,448411 & 0,524835 & 0,573409 & 0,633134 \\
\hline 10 & 10 & 2574,12 & 2,445301 & 3,500018 & 4,096541 & 4,475677 & 4,941859 \\
\hline \multirow[t]{2}{*}{11} & 11 & 4081,72 & 4,453628 & 6,374583 & 7,461028 & 8,151551 & 9,000606 \\
\hline & & & & 11,28173 & 13,20453 & 14,42661 & 15,92927 \\
\hline \multirow[t]{2}{*}{12} & 12 & 2224,80 & 7,882032 & 9 & 3 & 9 & 9 \\
\hline & & & & 11,93578 & 13,97005 & 15,26298 & 16,85276 \\
\hline 13 & 13 & 1464,68 & 8,338987 & 6 & 4 & 8 & 4 \\
\hline \multirow[t]{2}{*}{14} & 14 & 1653,56 & 3,484639 & 4,987645 & 5,837712 & 6,377994 & 7,042319 \\
\hline & & & & 10,17086 & 11,90432 & 13,00607 & 14,36077 \\
\hline 15 & 15 & 2388,72 & 7,105916 & 3 & 6 & 8 & 6 \\
\hline 16 & 16 & 280,08 & 0,846645 & 1,211823 & 1,418359 & 1,549629 & 1,711037 \\
\hline \multirow[t]{2}{*}{17} & 17 & 1828,48 & 3,614917 & 5,174116 & 6,055962 & 6,616443 & 7,305605 \\
\hline & & & & & & 10,10000 & 11,15200 \\
\hline 18 & 18 & 4787,96 & 5,518171 & 7,898286 & 9,244424 & 1 & 5 \\
\hline 19 & 19 & 1,36 & 0,016832 & 0,024092 & 0,028198 & 0,030809 & 0,034018 \\
\hline \multirow[t]{2}{*}{20} & 20 & 4,80 & 0,047501 & o,067989 & 0,079577 & 0,086942 & 0,095998 \\
\hline & & & 17,92814 & 25,66097 & 30,03448 & 32,81419 & 36,23207 \\
\hline 21 & 21 & 2781,72 & 7 & 6 & 3 & o & 8 \\
\hline \multirow[t]{2}{*}{22} & 22 & 192,04 & 0,575156 & 0,823235 & 0,963542 & 1,052719 & 1,162368 \\
\hline & & & 10,62684 & 15,21045 & 17,80283 & 19,45049 & 21,47644 \\
\hline \multirow[t]{2}{*}{23} & 23 & 1613,12 & 7 & 5 & 8 & 8 & o \\
\hline & & & 14,03928 & 20,09476 & 23,51959 & 25,69634 & 28,37285 \\
\hline \multirow[t]{2}{*}{24} & 24 & 1898,44 & 9 & 3 & 8 & 8 & o \\
\hline & & & 12,33073 & 17,64927 & 20,65731 & 22,56916 & 24,91993 \\
\hline \multirow[t]{2}{*}{25} & 25 & 1412,76 & 9 & 6 & 6 & O & 9 \\
\hline & & & & 13,97988 & 16,36253 & 17,87689 & 19,73893 \\
\hline 26 & 26 & 2285,20 & 9,767103 & 5 & 6 & 6 & 3 \\
\hline 27 & 27 & 2224,52 & 3,278022 & 4,691909 & 5,491571 & 5,999819 & 6,624753 \\
\hline
\end{tabular}




\begin{tabular}{|c|c|c|c|c|c|c|c|}
\hline \multirow{3}{*}{$\begin{array}{c}\text { Num } \\
\text { ber }\end{array}$} & \multirow{3}{*}{$\begin{array}{c}\text { Sub } \\
\text { Subwatershe } \\
\text { d }\end{array}$} & $\begin{array}{c}\text { Sub } \\
\text { Subwatershed } \\
\text { Area }\end{array}$ & $\begin{array}{c}\mathrm{Q} \\
\text { Return } \\
\text { Period }\end{array}$ & $\begin{array}{c}\mathrm{Q} \\
\text { Return } \\
\text { Period }\end{array}$ & $\begin{array}{c}\mathrm{Q} \\
\text { Return } \\
\text { Period }\end{array}$ & $\begin{array}{c}\text { Q } \\
\text { Return } \\
\text { Period }\end{array}$ & $\begin{array}{c}\text { Q } \\
\text { Return } \\
\text { Period }\end{array}$ \\
\hline & & & 1.01 Year & 2 Years & 5 Years & 10 Years & 25 Years \\
\hline & & (Ha) & $\left(\mathrm{m}^{3} / \mathrm{sec}\right)$ & $\left(\mathrm{m}^{3} / \mathrm{sec}\right)$ & $\left(\mathrm{m}^{3} / \mathrm{sec}\right)$ & $\left(\mathrm{m}^{3} / \mathrm{sec}\right)$ & $\left(\mathrm{m}^{3} / \mathrm{sec}\right)$ \\
\hline \multirow[b]{2}{*}{28} & & & & & 11,50434 & 12,56907 & 13,87825 \\
\hline & 28 & 1674,48 & $\begin{array}{l}6,867159 \\
13,21674\end{array}$ & $\begin{array}{l}9,829125 \\
18,91744\end{array}$ & $\begin{array}{c}3 \\
22,14161\end{array}$ & $\begin{array}{c}6 \\
24,19083\end{array}$ & $\begin{array}{c}7 \\
26,71052\end{array}$ \\
\hline 29 & 29 & 4468,48 & $\begin{array}{c}7 \\
15,19414\end{array}$ & $\begin{array}{c}1 \\
21,74773\end{array}$ & $\begin{array}{c}9 \\
25,45428\end{array}$ & $\begin{array}{c}6 \\
27,81009\end{array}$ & $\begin{array}{c}7 \\
30,70676\end{array}$ \\
\hline 30 & 30 & 2922,56 & $\begin{array}{c}3 \\
24,91082\end{array}$ & $\begin{array}{c}2 \\
35,65545\end{array}$ & $\begin{array}{c}9 \\
41,73236\end{array}$ & $\begin{array}{c}5 \\
45,59471\end{array}$ & $\begin{array}{c}3 \\
50,34380\end{array}$ \\
\hline 31 & 31 & 4546,80 & 8 & 4 & 2 & 1 & 5 \\
\hline
\end{tabular}

Source: Analysis Results, 2019

In calculating the erosion rate, the formula formula MUSLE (Modify Universal Soil Loss Equation) is used

$\mathrm{A}=\mathrm{R}_{\mathrm{W}} \times \mathrm{K} \times \mathrm{LS} \times \mathrm{CP}$

(Formula 6)

Where $: \mathrm{R}_{\mathrm{W}}=9,05\left(\mathrm{~V}_{\mathrm{O}} \times \mathrm{Q}_{\mathrm{p}}\right)^{\mathrm{o}, 56}$

From this formula, Value of $\mathrm{CP}$ related to factors of land use and land management and $\mathrm{V}_{\mathrm{O}}$ means urface runoff volume $\left(\mathrm{m}^{3}\right)$. Symbol A means erosion eate (tons/ha/year), $\mathrm{R}_{\mathrm{W}}$ means surface runoff erosivity index (run-off). Furthermore, $\mathrm{K}$ is equal to soil erodibility factor and LS is Slope factor.

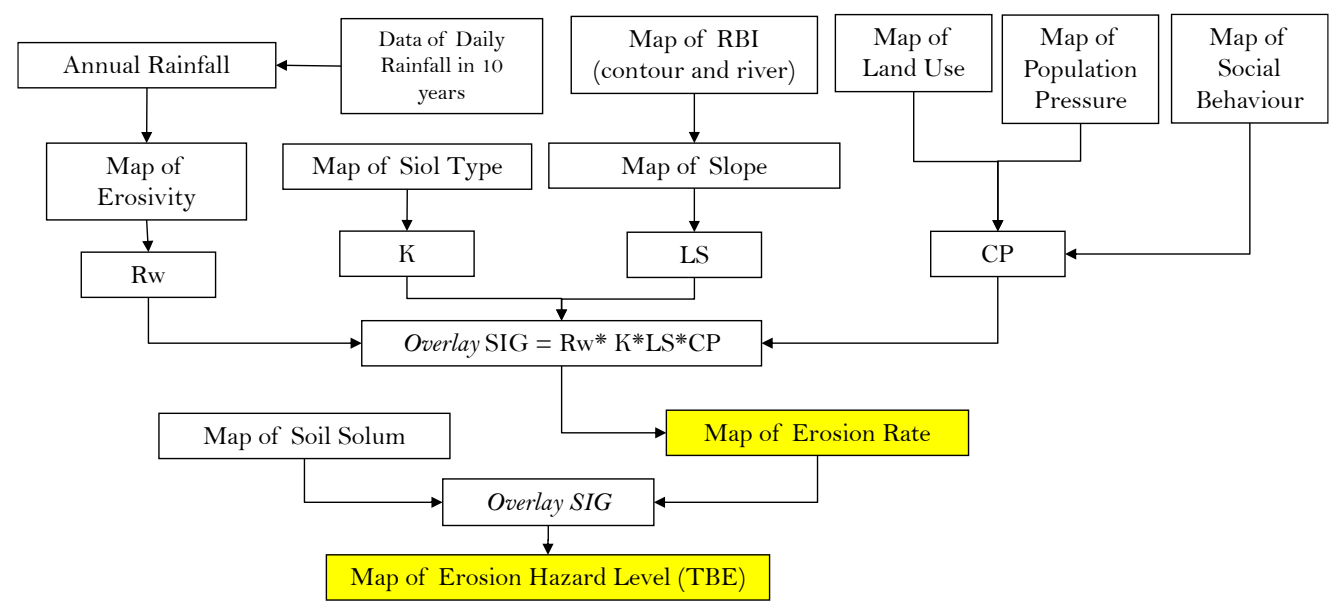

Figure 5. Flow Analysis of Erosion Rates and Erosion Hazard Levels in Lesti Sub Watershed

Source: Analysis Results, 2021 


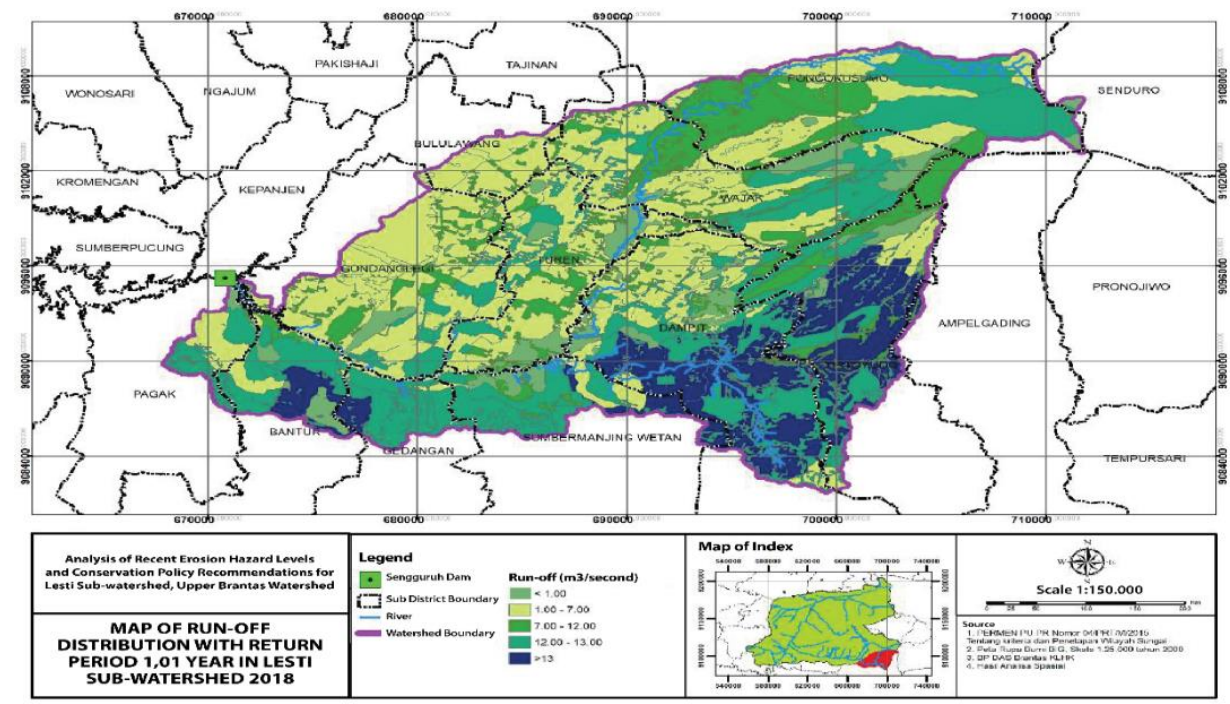

Figure 6. Runoff Distribution Map of Lesti Subwatershed

Source: Analysis Results, 2021

Based on the final results of calculation, the erosion rate (current) of this area is 153,868 tons / ha / year. When compare with tolerable erosion rate of 30 tons / ha / year, this area is out of tolerate of erosion. Lesti Subwatershed need to get specific and targeted conservation directions so that efforts are made more effective and efficient. The rate of erosion in Lesti Subwatershed has an effect on the level of erosion hazard in the area. Erosion Hazard Level Category (EHL) estimates the maximum soil loss on a land (Utomo, 1994; Suresh, 1993).

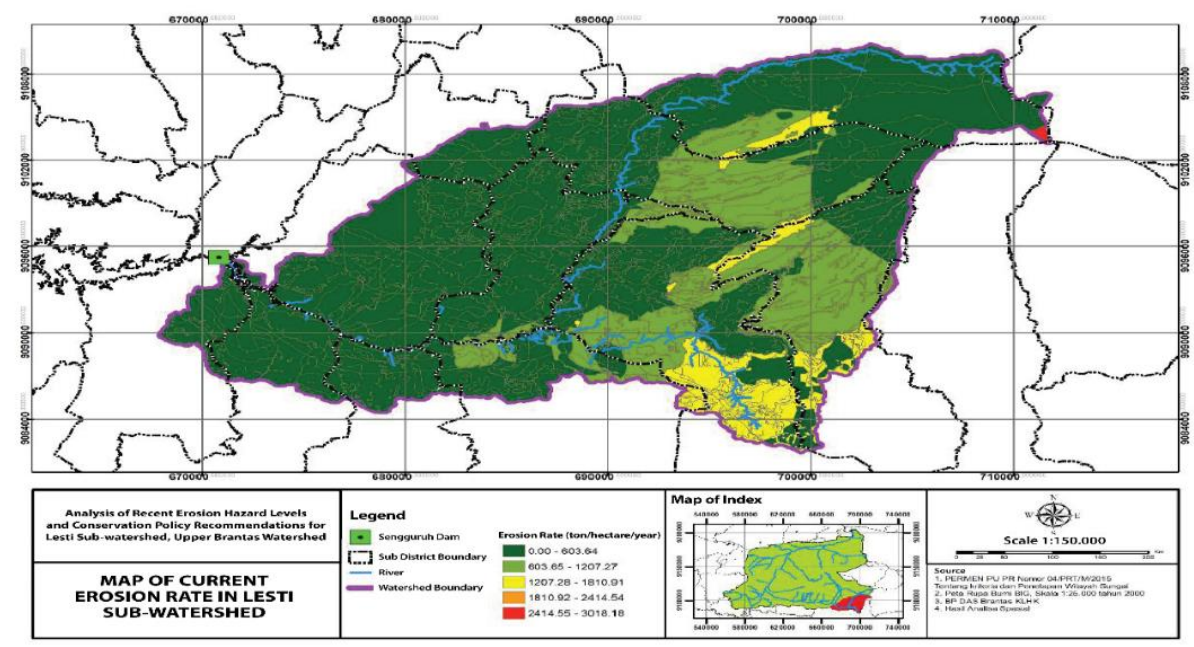

Figure 7. Current Erosion Rate Map of Lesti Subwatershed

Source: Analysis Results, 2021 
Environmental conservation analysis is carried out by taking into account the population pressure on the land of each Subdistrict (economic aspects) and behavior analysis of the people of each Subdistrict (social aspects) as part of the consideration. Qualitative and quantitative analysis through overlay techniques in the concept of Geographic Information Systems refers to 3 maps and their attributes, namely the Erosion Hazard Levels (EHL), Population Pressure Maps for Land in each Subdistrict and the Community Behavior Map in each Subdistrict in Lesti Subwatershed.

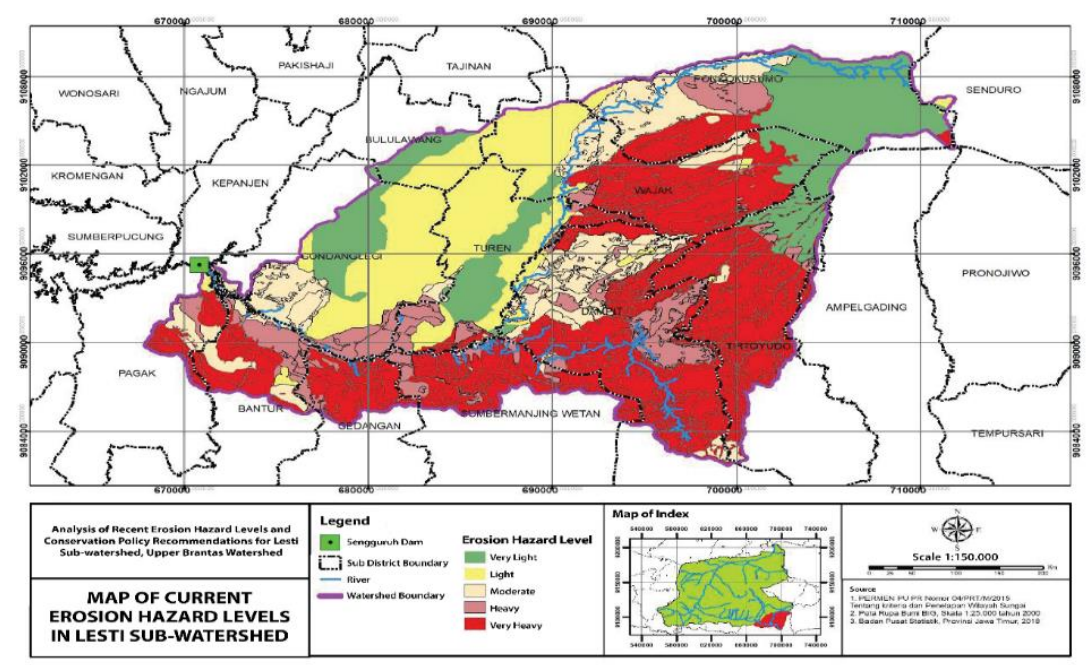

Figure 8. Current Erosion Hazard Levels Map of Lesti Subwatershed

Source: Analysis Results, 2021

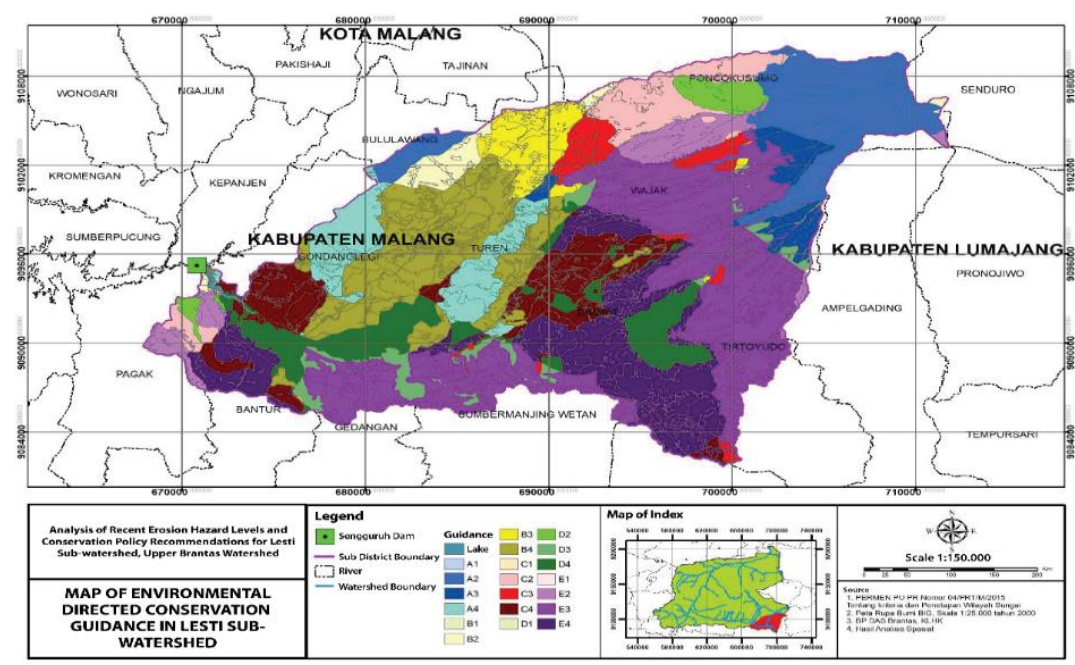

Figure 9. Environmental-directed Conservation Guidance Map of Lesti Subwatershed Source: Analysis Results, 2021 
Giving recommendations also considers the current land use conditions as recommendations that are more in line with field conditions so that it is expected to be more targeted. In addition to the 6 priority Subdistricts, also given environmental conservation directions in 6 other districts that have a lower level of Erosion Hazard Level (EHL) are given while taking into account existing land use.

Table 10. Directions for Subwatershed Conservation in 6 Priority Subdistricts

\begin{tabular}{|c|c|c|}
\hline Sub-District & Conservation Direction & $\begin{array}{l}\text { Current dominant } \\
\text { Land Use }\end{array}$ \\
\hline Wajak & $\begin{array}{l}\text { Wajak sub-district with the land use forf paddy fields } \\
\text { and settlements is recommended to take conservation } \\
\text { actions in the form of law enforcement or counseling, } \\
\text { and community empowerment to increase } \\
\text { community capacity and independence through } \\
\text { providing access to resources, education and training. } \\
\text { In dry land agricultural areas and plantation forests, } \\
\text { it is advisable to carry out conservation activities in } \\
\text { an agronomic manner by using wood cover } \\
\text { vegetation, shrubs, grasses and other cover } \\
\text { vegetation. }\end{array}$ & $\begin{array}{l}\text { Rice fields, dry land } \\
\text { agriculture, } \\
\text { settlements, } \\
\text { plantation forests }\end{array}$ \\
\hline Tirtoyudo & $\begin{array}{l}\text { Tirtoyudo Subdistrict, with land use dominated by } \\
\text { mixed dryland agricultural land, settlements, } \\
\text { plantations, and dry land agriculture, is } \\
\text { recommended to take conservation actions in the } \\
\text { form of law enforcement or counseling, and } \\
\text { community empowerment to increase community } \\
\text { capacity and independence through providing access } \\
\text { to resources, education and training. In areas that } \\
\text { are already in the form of plantations, it is } \\
\text { recommended to leave them untreated without } \\
\text { intervention because they are in accordance with } \\
\text { environmental conservation principles. }\end{array}$ & $\begin{array}{c}\text { Mixed Dryland } \\
\text { Agriculture, } \\
\text { Settlements, } \\
\text { Plantation, Dry Land } \\
\text { Agriculture, } \\
\text { Plantation Forest }\end{array}$ \\
\hline Dampit & $\begin{array}{l}\text { Dampit sub-district with land use is dominated by } \\
\text { residential land, mixed dry land farming, dry land } \\
\text { agriculture, and rice fields have a very heavy erosion } \\
\text { hazard level with large population pressure and } \\
\text { negative behavior. In some areas of a certain scale, it } \\
\text { can be suggested that efforts to provide } \\
\text { environmental awareness education and technical } \\
\text { civil development in the form of terracing mounds } \\
\text { equipped with reinforcing grass and water channels } \\
\text { on the upper slopes. }\end{array}$ & $\begin{array}{c}\text { Settlements, Mixed } \\
\text { Dry Land } \\
\text { Agriculture, Dry } \\
\text { Land Agriculture, } \\
\text { Rice Fields }\end{array}$ \\
\hline $\begin{array}{l}\text { Sumbermanjing } \\
\text { Wetan }\end{array}$ & $\begin{array}{l}\text { Sumbermanjing Wetan Subdistrict, with land use } \\
\text { dominated by mixed dryland agricultural land and } \\
\text { settlements, is recommended to take conservation } \\
\text { actions in the form of law enforcement or counseling, } \\
\text { and community empowerment to increase } \\
\text { community capacity and independence through } \\
\text { providing access to resources, education and training. } \\
\text { Meanwhile, in certain areas that have land use in the } \\
\text { form of plantations, agronomic conservation efforts } \\
\text { can be made to keep the run-off rate even lower by } \\
\text { using wood cover vegetation, shrubs, grasses and } \\
\text { other cover vegetation. }\end{array}$ & $\begin{array}{l}\text { Mixed Dry Land } \\
\text { Agriculture, } \\
\text { Settlements, } \\
\text { Plantation Forest }\end{array}$ \\
\hline Gedangan & $\begin{array}{l}\text { Gedangan Subdistrict, whose land use is dominated } \\
\text { by mixed dryland agricultural land, settlements, rice }\end{array}$ & $\begin{array}{l}\text { Mixed dry land } \\
\text { agriculture, }\end{array}$ \\
\hline
\end{tabular}




\begin{tabular}{|c|c|c|}
\hline Sub-District & Conservation Direction & $\begin{array}{l}\text { Current dominant } \\
\text { Land Use }\end{array}$ \\
\hline & $\begin{array}{l}\text { fields, is recommended to take conservation actions } \\
\text { in the form of law enforcement or counseling, and } \\
\text { community empowerment to increase community } \\
\text { capacity and independence through providing access } \\
\text { to resources, education and training. In certain areas } \\
\text { that have a very severe level of erosion hazard with } \\
\text { large population pressure and negative behavior, it is } \\
\text { recommended to relocate small-scale residents. }\end{array}$ & $\begin{array}{l}\text { settlements, rice } \\
\text { fields }\end{array}$ \\
\hline Bantur & $\begin{array}{l}\text { Bantur sub-district with land use is dominated by } \\
\text { mixed dry land agricultural lands, settlements, } \\
\text { plantations, it is recommended to take conservation } \\
\text { actions in the form of law enforcement or counseling, } \\
\text { and community empowerment to increase } \\
\text { community capacity and independence through } \\
\text { providing access to resources, education and training. } \\
\text { In certain areas that have a very severe level of } \\
\text { erosion hazard with large population pressure and } \\
\text { negative behavior, it is recommended to relocate } \\
\text { small-scale residents. }\end{array}$ & $\begin{array}{l}\text { Mixed Dry Land } \\
\text { Agriculture, } \\
\text { Settlements, } \\
\text { Plantation Forest }\end{array}$ \\
\hline
\end{tabular}

Source: Analysis Result, 2021

\section{CONCLUSIONS AND RECOMMENDATIONS}

Based on the analysis results, both spatially, statistically and numerically, several conclusions are given to answer research questions. In the Lesti Subwatershed, there is a correlation between community behavior and population pressure with current land use, which results in erosion vulnerability. In Subdistricts that have a population pressure value> 1 and negative behavior in general are directly proportional to the condition of erosionprone land use and lands with high runoff coefficient values such as settlements, dry land paddies or open land. In Subdistricts with low population pressure and positive behavior is characterized by the use of vegetation-covered land such as plantations and mixed agriculture which in theory watershed conservation is very good at reducing the rate of erosion.

Calculation results by authors show that the current erosion rate in each hectare of land (average erosion rate) in the Lesti Subwatershed is 153.868 tons/ha/year. This is not in accordance with the erosion rate that can be tolerated in the Lesti Subwatershed, which is 30 tons/ha/year. There is a very large gap of 123.868 tons/ha/year so that it requires watershed conservation in priority areas to reduce the erosion rate in the future. Based on the calculations results by the authors and from previous researchers, it can be said that there has always been an increase in the erosion rate since the last 14 years. The result of overlaying the erosion rate with soil solum shows that conservation direction is prioritized in 6 Subdistricts with a high erosion hazard level, namely Wajak Subdistrict, Tirtoyudo Subdistrict, Dampit Subdistrict, Sumbermanjing Wetan Subdistrict, Gedangan Subdistrict and Bantur Subdistrict.

Future direction of watershed conservation in Lesti Subwatershed requires an environmental science-based approach that considers social aspects (community behavior), economic aspects (population pressure) and environmental aspects (land use / environmental 
carrying capacity). There are 2 principles of environmental science that can be considered in the future direction of conservation, namely the principle of interaction and sustainability. Watershed conservation paradigm as a derivative of Law no. 37 of 2014 in the form of a Draft of Government Regulation currently being compiled by the government needs to pay more attention to ecological concepts that involve the fulfillment of human and natural needs in more synergy according to their respective roles. This research found a new idea, namely environmental education and relocation of small-scale population that can be input into the Draft of Government Regulation. Relocation of small-scale population is needed especially in priority areas where population pressure is high, community behavior is negative and the erosion hazard level is very heavy. Nevertheless, the selection of new locations resulting from relocation must still consider aspects of social, economic and environmental needs so as not to cause other problems in the future.

Based on the conclusions, several suggestions/recommendations can be established, both per conservation priority area, and general recommendations from the point of view of environmental science, as follows:

a) Wajak Subdistrict with the use of paddy fields and settlements are advised to take conservation measures in the form of law enforcement or counseling, and community empowerment to increase the ability and independence of the community through providing access to resources, education, and training. In dryland agricultural areas and plantations, it is recommended to carry out agronomic conservation activities using cover vegetation of woody plants, shrubs, grasses, and other cover vegetation.

b) Tirtoyudo Subdistrict with land use dominated by mixed upland, settlements, plantation, and dryland agriculture is recommended to take conservation measures in the form of law enforcement or counseling, and community empowerment to increase the ability and independence of the community through providing access to resources, education, and training. In areas that are already in the form of plantations, it is recommended to be left naturally without intervention because it is following the environmental conservation principles

c) Dampit Subdistrict with land use dominated by settlement, mixed upland agriculture, dryland agriculture, paddy fields have a very high erosion hazard level with large population pressure and negative behavior is recommended for gradual relocation of the population. In some areas of a certain scale, it can be suggested efforts to provide environmental awareness education and technical civil development in the form of making guludan terraces which are equipped with reinforcement grass and waterways on the upper slopes

d) Sumbermanjing Wetan Subdistrict with land use dominated by mixed upland agriculture land and settlement, it is recommended to carry out conservation actions in the form of law enforcement or counseling, and community empowerment in the context of increasing community capacity and independence through providing access to resources, education, and training. Meanwhile, in certain areas that have land use in the form of plantation forest, agronomic conservation efforts can be made to keep the run-off rate even lower by using cover vegetation of woody plants, shrubs, grasses, and other cover vegetation.

e) Gedangan Subdistrict with land use dominated by mixed upland agriculture, settlement, paddy fields, it is recommended to take conservation measures in the form of law 
enforcement or counseling, and community empowerment to increase the capacity and independence of the community through providing access to resources, education, and training. In certain areas which have a very high erosion hazard level with large population pressure and negative behavior, it is recommended to relocate a small-scale population.

f) Bantur Subdistrict with land use dominated by mixed upland agriculture lands, settlements, plantations it is recommended to take conservation measures in the form of law enforcement or counseling, and community empowerment to increase the capacity and independence of the community through providing access to resources, education, and training. In certain areas which have a very high erosion hazard level with large population pressure and negative behavior, it is recommended to relocate a small-scale population.

g) When the conservation directives for behavioral improvement through environmental education have been successful individually by the community, then it needs to be developed into a value system that is integrated and wide-scale watershed scope. The value system in the community such as cooperation needs to be encouraged again. This system already exists in the lives of rural communities, but needs to be raised again on a broader scale, even if it needs to be made a common philosophy in one goal namely environmental care for better watershed health. Mutual cooperation is a shared value system of Indonesian society where personal values such as volunteerism, togetherness, and tolerance can be accumulated in the transformation of a unique joint movement.

\section{References}

Anache, J. A. A., Flanagan, D. C., Srivastava, A., \& Wendland, E. C. (2018). Land use and climate change impacts on runoff and soil erosion at the hillslope scale in the Brazilian Cerrado. Science of The Total Environment, 622-623, 140151. doi:10.1016/j.scitotenv.2017.11.257

Ariani, D.R. \& Harini, R. (2012). Tekanan penduduk terhadap lahan pertanian di kawasan pertanian. Jurnal Bumi Indonesia. Volume 1, Nomor 3, Tahun 2012

Arsyad, Sitanala. (2006). Konservasi Tanah dan Air. Bogor : IPB Press

Asdak, Chay. (2010). Hidrologi dan Pengelolaan Daerah Aliran Sungai. Edisi Kelima (Revisi). Yogyakarta: Gadjah Mada University Press.

Bappenas. (2015). Kajian Pengaruh Kebijakan Konservasi Sumber Daya Air di dalam DAS Terhadap Sektor Kehutanan dan Sektor lainnya. Jakarta: Bappenas.

Bappenas. (2012). Kajian Analisis Perubahan Penggunaan Lahan di Ekosistem DAS dalam Menunjang Ketahanan Air dan Ketahanan Pangan, Studi Kasus DAS Brantas. Jakarta: Bappenas.

Bellfield, B., Leggett, M., Trivedi, M., Pareira, J., Gangga, A. (2016). How Can Indonesia Achieve Water, Energy and Food Security? Jakarta: WCS and Global Canopy Programme.

Bisri M., Limantara L.M., Prasetyorini L., Chasanawati D. (2017). Application of the Kineros model for predicting the effect of land use on the surface run-off. Case study in Brantas Subwatershed, Klojen District, Malang City, East Java Province of Indonesia. Journal of Water and Land Development No. 35 p. 3-9. Polish Academy of Sciences (PAN) in Warsaw.doi:10.1515/jwld-2017-0062. 
Common, M. \& Stagl, S. (2005). Ecological Economic: An Introduction. New York: Cambridge University Press.

Djajasinga, V., Masrevaniah, A., \& Juwono, P.T. (2012). Kajian Ekonomi Penanganan Sedimen Pada Waduk Seri Di Sungai Brantas (Sengguruh, Sutami Dan Wlingi). Jurnal Teknik Pengairan, Volume 3, Nomor 2, Desember 2012, hlm 143-152. E - ISSN : 24776068. P - ISSN : 2086-1761. Universitas Brawijaya, Malang.

Euler, J., \& Heldt, S. (2018). From information to participation and self-organization: Visions for European river basin management. Science of The Total Environment, 621, 905914. doi:10.1016/j.scitotenv.2017.11.072

Firdaus, W., Sayekti, R.W., Prasetyorini, L. (2015). Studi Penentuan Kinerja Kelestarian dan Sosial Pengelolaan DAS di Sub DAS Lesti. Jurnal Teknik Pengairan. E - ISSN : 2477-6068. P - ISSN : 2086-1761. Universitas Brawijaya, Malang.

Hardjowigeno S. (1995). Ilmu Tanah. Jakarta: Akademika Pressindo.

Heathcote, I. (1998). Integrated Watershed Management: Principles and Practice. New York: John Wiley \& Sons.

Jeloudar, F. T., Sepanlou, M.G., Emadi, S.M. (2018). Impact of land use change on soil erodibility. Global Journal Environment Science Manage.,4(1): 59-70. DOI: 10.22034/gjesm.2018.04.01.006

Kindu, M., Schneider, T., Döllerer, M., Teketay, D., \& Knoke, T. (2018). Scenario modelling of land use/land cover changes in Munessa-Shashemene landscape of the Ethiopian highlands. Science of The Total Environment, 622-623, 534546. https://doi.org/10.1016/j.scitotenv.2017.11.338

Ma’wa, J., Andawayanti, U., Juwono, P.T.(2015). Studi Pendugaan Sisa Usia Guna Waduk Sengguruh dengan Pendekatan Erosi dan Sedimentasi. Jurnal Jurusan Pengairan Fakultas Teknik Universitas Brawijaya.

Nabi, G., Hussain, F., Wu, R.-S., Nangia, V., Bibi, R., and Majid, A. (2017). Optimizing micro watershed management for soil erosion control under various slope gradient and vegetation cover conditions using SWAT modeling. Hydrol. Earth Syst. Sci. Discuss., https://doi.org/10.5194/hess-2017-532.

Pambudi, A.S., Moersidik, S.S., \& Karuniasa, M. (2020). Keterkaitan Perilaku Masyarakat dengan Penggunaan Lahan dan Erosivitas Limpasan Permukaan di Sub DAS Lesti, Kab. Malang (Relationship between community behavior with land use and surface runoff erosivity in Lesti Subwatershed, Malang District). Jurnal Penelitian Pengelolaan Daerah Aliran Sungai (Journal of Watershed Management Research). Vol. 4, No. 2 (2020). doi https://doi.org/10.20886/jppdas.2020.4.2.155-172

Pambudi, A.S. \& Moersidik, S.S. (2019). Conservation direction based on estimation of erosion in Lesti Subwatershed, Malang District. International Proceeding IOP Conference Series: Earth and Environmental Science,Volume 399, The 1st International Seminar on Natural Resources and Environmental Management 2019. Published under licence by IOP Publishing Ltd. doi: 10.1088/1755-1315/399/1/012097

Pambudi, Andi Setyo. (2019). Watershed Management in Indonesia: A Regulation, Institution, and Policy Review. The Indonesian Journal of Development Planning, 3(2), 185-202. ISSN: 2654-2625 (Online) ISSN: 2598-0807 (Print). https://doi.org/10.36574/jpp.v3i2.74. 
GoI. (2014a). Peraturan Presiden Nomor 2 Tahun 2015 tentang Rencana Pembangunan Jangka Menengah Nasional Tahun 2015 - 2019. Jakarta

GoI. (2014b). Undang-undang Nomor 37 Tahun 2014 tentang Konservasi Tanah dan Air. Jakarta

Reddy, V.R., Saharawat, Y. S., \& George, B. (2017). Watershed management in South Asia: A synoptic review. Journal of Hydrology, 551, 4-13. doi:10.1016/j.jhydrol.2017.05.043

Rusli, S., Widono, S., \& Indriana, H. (2009), Tekanan penduduk dan, overshoot ekologi pulau jawa, dan masa pemulihannya. Jurnal Sodalit: Jurnal Sosiologi Pedesaan. Vol. 3 No. 1 (2009). DOI: https://doi.org/10.22500/sodality.v3i1.5871

Sapci, O., \& Considine, T. (2014). Evaluasi potensi degradasi lahan dengan menggunakan Analisis kemampuan lahan dan tekanan penduduk terhadap lahan pertanian di Kecamatan Kokap Kabupaten Kulon Progo. Forum Geografi , 1-12. Journal of Behavioral and Experimental Economics The Sartohadi J, P. F.

Setyawan C. \& Lee,.C.Y (2017). GIS application for sediment delivery ratio assessment in tropical river basin. Journal of Scientific and Engineering Research, 2017, 4(4):1 16-122

Setyono \& Prasetyo. (2012). Analisis Tingkat Bahaya Erosi Pada Sub DAS Lesti Kabupaten Malang Menggunakan Sistem Informasi Geografis. Media Teknik Sipil, Volume 10, Nomor 2, Agustus 2012: 114-127DOI: https://doi.org/10.22219/jmts.v10i2.1786

Soemarwoto, Otto. (1985). Ekologi, Lingkungan Hidup dan Pembangunan. Jakarta: Jambatan.

Soemarto, C.D. (1987). Hidrologi Teknik. Penerbit Usaha Nasional. Surabaya.

Suresh, R. (1993). Soil and Water Conservation Engineering. Nem Chand Jain, Delhi : Standard Publisher Distributors Nai Sarak

Utomo, Wani Hadi. (1994). Erosi dan Konservasi Tanah. Malang: IKIP

Yupi, Haiki Mart. (2006). Studi Model WEPP (Water Erosion Prediction Project) Dalam Upaya Pengaturan Fungsi Kawasan Pada Sub DAS Lesti Berbasis Sistem Informasi Geografi (SIG). Tesis: Universitas Brawijaya 